DOI https://doi.org/10.18551/rjoas.2018-08.40

\title{
THE INFLUENCE OF ORGANIZATIONAL CULTURE ON THE EMPLOYEE PERFORMANCE MEDIATED BY WORK ETHIC: AN EMPERICAL STUDY AT PT BANK NEGARA INDONESIA (PERSERO) TBK KEDIRI BRANCH, EAST JAVA
}

\author{
Rohi Sapta Parestu* \\ Master's Program, Faculty of Economic and Business, University of Brawijaya, Indonesia \\ Sudiro Achdmad, Irawanto Dodi W. \\ Faculty of Economic and Business, University of Brawijaya, Indonesia \\ *E-mail: sapta.rohi@bni.co.id
}

\begin{abstract}
The impact of globalization demands the banking industry to always improve its ability to provide banking solutions to all customers of PT Bank Negara Indonesia (Persero) Tbk Kediri Branch. This study aims to evluate the influence of organizational culture on employee performance through work ethic. Data analysis technique uses structural model approach of Partial Least Square assistance of Smarth PLS program 3.2.7. The findings show that there is an organizational culture influence on performance through work ethic. This finding implies the importance of a high work ethic that must be entrusted to Bank Negara Indonesia.
\end{abstract}

\section{KEY WORDS}

Globalization, organizational culture, work ethic, performance.

Problems regarding human resources at this time are still the center of attention for companies, especially banks. Along with the development of science and technology, human resources need a lot of innovation and creativity in order to be able to balance the progress, so that the performance is in line with the expectations of a company. Employee performance is one of the conditions for the company to achieve its goals. The achievement of the company's goals is derived from the company's efforts to manage potential human resources so that it can improve its work. Therefore, employee performance is something that should be considered by the company leader.

Organizational culture is the principal problem solving internally and externally which is carried out consistently by a group which is then developed and inherited to overcome external adaptation problems and internal integration problems. An organizational culture is a form of beliefs, values, or ways that can be learned to overcome and live in an organization. Organizational culture is well implemented through organizational members. Robbins (2001) defines organizational culture as a value system that is a guideline and carried out by members of the organization, so that it can be distinguished from other organizations. Organizational culture as a cognitive framework which consists of attitudes, values, rules, norms, attitudes, and expectations that belong to the members of the organization and the characteristics of the company so that employees can work as desired by the company (Greenberg and Baron, 2003)

Related to what was stated above PT Bank Negara Indonesia, Tbk is one of the companies engaged in banking services which is the oldest commercial bank in the history of Indonesia. The the bank was established on July 5, 1946. BNI currently has 169 branch offices, 911 service offices in Indonesia and 5 overseas. The role of Bank Negara Indonesia Tbk to support the Indonesian the economy is increasingly strategic with the emergence of initiatives to serve all levels of society from Sabang to Merauke in the 1960s by introducing various banking services.

The impact of globalization also demands the banking industry to always improve its ability to provide banking solutions to all customers. PT Bank Negara Indonesia, Tbk. A focus on corporate banking that is supported by a strong retail banking infrastructure and 
continuously strives to increase capitalization are the hallmarks of PT Bank Negara Indonesia, Tbk. But from everyday reality that can be observed in the field, especially PT Bank Negara Indonesia, Tbk. Kediri branch, the condition of employee discipline is still visible. Many of the employee's work do not fully follow the rules or work procedures that should be obeyed. The low culture of innovation for each employee and the lack of responsiveness of employees to customers are also often found in PT Bank Negara Indonesia, Tbk. Kediri branch. This organizational culture problem often causes employee performance to decline.

The reason behind this research is that employee performance is still not optimal, most employees have egocentric in each unit causing a lack of totality of employee work involvement in activities organized by the company, work that is only used as a routine without developing themselves in the company, and the severity again employees only know conceptually about the company's goals but are reluctant to engage further in realizing the achievement of company goals. This is also a problem that occurred at PT Bank Negara Indonesia, Tbk. Kediri branch which causes employee performance to decline. Employee performance at PT Bank Negara Indonesia in Table 1.

Table 1 - Employee Performance

\begin{tabular}{|c|c|c|c|c|c|c|}
\hline \multicolumn{7}{|c|}{ DPK } \\
\hline \multirow{2}{*}{ BRANCH } & \multirow{2}{*}{ Des-16 } & \multirow{2}{*}{$\begin{array}{c}\text { Goal } \\
\text { Dec-17 }\end{array}$} & \multicolumn{2}{|c|}{ Realization } & \multicolumn{2}{|c|}{ Achiev Goal FY } \\
\hline & & & Nov-17 & 31-Des-17 & $\mathrm{Rp} M$ & $\%$ \\
\hline Total DPK & $1.870,0$ & $2.443,8$ & $2.244,1$ & $2.223,2$ & $(220,65)$ & $91,0 \%$ \\
\hline Savings & 722,4 & 902,3 & 953,9 & 951,9 & 49,60 & $105,5 \%$ \\
\hline Giro & 130,9 & 151,7 & 308,9 & 268,0 & 116,28 & $176,7 \%$ \\
\hline Deposit & $1.016,7$ & $1.389,9$ & 981,3 & $1.003,3$ & $(386,53)$ & $72,2 \%$ \\
\hline Casa & $45,63 \%$ & $\begin{array}{l}43,13 \% \\
\text { Credit }\end{array}$ & $56,27 \%$ & $54,87 \%$ & & \\
\hline \multirow{2}{*}{ Branch / Centra } & \multirow{2}{*}{ BD 2016 Migration } & Goal *) & \multicolumn{2}{|c|}{ Realization } & \multicolumn{2}{|c|}{ Achiev Goal FY } \\
\hline & & Dec-17 & Nov-17 & 31-Des-17 & IDR M & $\%$ \\
\hline Credit Consumer & 107,8 & 159,0 & 171,7 & 172,2 & 13,3 & $108,4 \%$ \\
\hline Griya & 79,2 & 88,6 & 125,7 & 125,5 & 36,9 & $141,6 \%$ \\
\hline Fleksi & 20,9 & 54,2 & 24,7 & 24,7 & $(29,5)$ & $45,6 \%$ \\
\hline Other & 7,8 & 16,1 & 21,3 & 22,0 & 5,9 & $136,5 \%$ \\
\hline Credit Small & 432,7 & 557,7 & 463,8 & 509,2 & $(48,6)$ & $91,3 \%$ \\
\hline Total Credit & 540,6 & 716,7 & 635,4 & 681,4 & $(35,3)$ & $95,1 \%$ \\
\hline
\end{tabular}

Source: www.bni.co.id

Table 1 shows that the total DPK of the office of Bank Negara Indonesia, Tbk of Kediri, achieved only reached $91.0 \%$ of the total full year 2017 target of 220.65 Melyar. While achieving total credit reached $95.1 \%$ of the full year 2017 target of 35.3 billion.

Research conducted by Nizam (2016) entitled "The effect of organizational culture on employees. The case performance of Singapore Tellecommunication" whose results suggest that Organizational Culture has a significant effect on employee performance, which means that the better the Organizational Culture by employees, the better the performance.

The research conducted by Alainein (2016) entitled "The Effect of Job Involvement on Job Performance at UNRWA Gaza Field Office" suggests that employee involvement has a significant positive effect on employee performance, this also suggests that the better the involvement of employees among employees, the better also it's performance. Based on the description of previous research, it can be seen that there is a research gap or research gap that can be entered by a researcher based on the experiences or findings of previous researchers, in this research the variables of Organizational Culture, Performance, Work Ethics and Employee Engagement.

The difference between this study and the previous research is the integration of the Organizational Culture, Performance, Work Ethics and Employee Involvement variables with different indicators and assessments and is the reason for the need for further research to answer the results of the existing research and in accordance with the delivered, 


\section{METHODS OF RESEARCH}

This research was conducted at the PT. Bank Negara Indonesia, Tbk. Kediri branch as many as 115 employees. This study uses an explanatory quantitative approach and data collection by survey method with a Saturated Sampling (Census) approach. Data were collected using questionnaires with 1-5 Likert scale. Data analysis technique using Partial Least Square, the assistance of Smart PLS packages 3.2.7.

\section{RESULTS OF STUDY}

Testing of Partial Least Square Structural Models. The Unidimensionality test of each construct is done by looking at the convergent validity of each construct indicator. According to Ghozali (2011) an indicator is said to have good reliability, if the value of outer loading or loading factor is greater than 0.70 , but the loading factor of 0.50 to 0.60 can still be maintained at the initial stage. Based on the above criteria, if found outer loading is below 0.50 it will drop from the model. The test is done by doing several tests: Convergent validity, Discriminant Validity and Composite Reliability as follows:

Convergent Validity Testing. Convergent validity calculation aims to find out instrument items that can be used as indicators of all latent variables. The convergent validity test results are measured based on the value of the loading factor (outer loading) of the laten (construct) indicator. Convergent validity test results which have the value of outer loading below 0.50 will drop from the model, and then the results of the initial analysis of the outer loading value can be seen as visualization Table 2 .

Table 2 - Convergent Validity Test

\begin{tabular}{|c|c|c|c|}
\hline Variable & Indicator & Outer loading & Description \\
\hline \multirow[t]{7}{*}{ Organizational Culture (X1) } & Innovation and risk taking (X1.1) & 0,794 & Valid \\
\hline & Attention to detail (X1.2) & 0.807 & Valid \\
\hline & Out come orientation (X1.3) & 0.833 & Valid \\
\hline & People orientation (X1.4) & 0.818 & Valid \\
\hline & Team orientation $(\mathrm{X} 1.5)$ & 0.65 & Valid \\
\hline & Aggresiveness (X1.6) & 0.254 & Invalid \\
\hline & Atability (X1.7) & 0.676 & Valid \\
\hline \multirow[t]{4}{*}{ Work Ethics (Z1) } & Hard work (Z1.1) & 0.939 & Valid \\
\hline & Discipline (Z1.2) & 0.845 & Valid \\
\hline & Honest and Responsible (Z1.3) & 0.81 & Valid \\
\hline & Diligent and diligent (Z1.4) & 0.201 & Invalid \\
\hline \multirow[t]{5}{*}{ Employee Performance (Y) } & Quantity (Y1.1) & 0.467 & Invalid \\
\hline & Quality (Y1.2) & 0.674 & Valid \\
\hline & Timeliness (Y1.3) & 0.701 & Valid \\
\hline & Effectiveness (Y1.4) & 0.787 & Valid \\
\hline & Presence (Y1.5) & 0.77 & Valid \\
\hline
\end{tabular}

Source: Analysis results processed, 2018.

Table 3 - Convergent Validity Test (Processed)

\begin{tabular}{|c|c|c|c|}
\hline Variable & Indicator & Outer loading & Description \\
\hline \multirow{7}{*}{ Organizational Culture (X1) } & Innovation and risk taking (X1.1) & 0,794 & Valid \\
\hline & Attention to detail (X1.2) & 0.809 & Valid \\
\hline & Out come orientation (X1.3) & 0.831 & Valid \\
\hline & People orientation (X1.4) & 0.817 & Valid \\
\hline & Team orientation (X1.5) & 0.648 & Valid \\
\hline & Atability (X1.7) & 0.677 & Valid \\
\hline & Hard work (Z1.1) & 0.943 & Valid \\
\hline \multirow[t]{2}{*}{ Work Ethics (Z1) } & Discipline (Z1.2) & 0.851 & Valid \\
\hline & Honest and Responsible (Z1.3) & 0.812 & Valid \\
\hline \multirow[t]{4}{*}{ Employee Performance (Y) } & Quality (Y1.2) & 0.629 & Valid \\
\hline & Timeliness (Y1.3) & 0.675 & Valid \\
\hline & Effectiveness (Y1.4) & 0.84 & Valid \\
\hline & Presence (Y1.5) & 0.823 & Valid \\
\hline
\end{tabular}

Source: Analysis results processed, 2018. 
Table 2 above shows that there are several indicators that have the outer loading value $\leq 0.50$ so it needs to drop out of the model, including X1.6, Z1.4, and Y1.1. After that, the data is tested again and the convergent validity test results can be seen as visualized in Table 3.

Table 3 is the result of the test again after the indicator that has the value of outer loading $>0.5$ is dropped and the test results show that all indicators have the value of outer loading above 0.6 . So that, the indicator meets the appropriate convergent validity criteria.

Discriminant validity. Discriminant validity is a measurement of reflexive indicators based on cross-loading with its latent variables. Another the method is by comparing the value of the square root of the average variance extracted (AVE) of each construct, with the correlation between other constructs in the model. In connection with this, it is recommended that the measurement value must be greater than 0.50 . Furthermore, the results of Discriminant Validity testing can be seen as visualized in Table 4.

Table 4 - Results of Discriminant Validity Testing

\begin{tabular}{ll}
\hline Variable & Average variance extracted (AVE) \\
\hline Organizational Culture (X1) & 0.587 \\
Work Ethics (Z1) & 0.758 \\
Employee Performance $(\mathrm{Y})$ & 0.558 \\
\hline
\end{tabular}

Source: Analysis results processed, 2018.

Table 4 shows the results of discriminant validity testing where all the values of Average variance extracted (AVE) are more basic than 0.50 . Thus it can be concluded that this measurement has met Convergent validity requirements based on the value of Average Variance Extracted (AVE).

Composite Reliability. Reliability composite testing aims to examine the validity of the instrument in a research model. The results of reliability composit testing can be seen as visualization of Table 5.

Table 5 - Test Results for Composite Reliability

\begin{tabular}{lll}
\hline Variable & Composite Reliability & Description \\
\hline Organizational Culture (X1) & 0.894 & Reliable \\
Work Ethics (Z1) & 0.903 & Reliable \\
Employee Performance (Y) & 0.833 & Reliable \\
\hline
\end{tabular}

Source: Analysis results processed, 2018.

Based on Table 5, can be explained the results of testing composite reliability that shows satisfactory value, where all latent variables have been reliable because all the variable values have a composite reliability value $\geq 0.70$. In other words, the questionnaire used as an instrument in this study is reliable or consistent. Thus it can be concluded that all indicators are indeed the measure of their respective constructs.

Modeling Structural Equations PLS Approach. This study uses a structural equation model approach to Partial Least Square (PLS). The results of testing the empirical model of this study can be seen 7 .

Goodness of Fit Model. The Goodness of Fit test for structural models in the inner model uses predictive-relevance $\left(Q^{2}\right)$ values. The $R 2$ value of endogenous variables in this study can be seen as visualized in Table 6 .

Table 6 - $R^{2}$ values of endogenous variables

\begin{tabular}{lll}
\hline & $R$ Square & $R$ Square Adjusted \\
\hline Work ethic (Z1) & 0.198 & 0.191 \\
Employee Performance $(\mathrm{Y})$ & 0.770 & 0.764 \\
\hline
\end{tabular}

Source: Analysis results processed, 2018. 
Goodness of Fit testing The structural model in the inner model uses predictiverelevance $\left(Q^{2}\right)$. $Q$ - Square predictive relavance $Q 2$ calculation is done by the formula:

$$
Q^{2}=1-\left(1-R_{1}{ }^{2}\right)\left(1-R_{2}{ }^{2}\right) \ldots\left(1-R_{p}{ }^{2}\right)
$$

Where: $R_{1}{ }^{2}, R_{2}{ }^{2} \ldots R_{p}{ }^{2}=R$-square endogenous variables in the $Q^{2}$ Interpretation model are the same as the total determination coefficient in path analysis (similar to $R^{2}$ in regression). According to Solimun (2014), the magnitude of $Q 2$ has a value with a range of $0<Q 2<1$, where getting closer to 1 means the model is getting better.

The results of the above calculation obtained $Q^{2}$ value of 0.8155 , the value is close to 1 , it can be concluded that the model is in a good category. This shows that $81.55 \%$ of the variability in the variable employee performance is explained by organizational culture while the remaining $18.45 \%$ is explained by variables that are not included in the model. Because $Q^{2}>0$ or $0.8155>0$, then the model can be said to be feasible because it has predictiverelevance $\left(Q^{2}\right)$ values that are relevant to this research model or fit into a fairly good category.

Hypothesis Testing Results. The results of testing the hypothesis with Partial Least Square show that of the three direct influences the hypothesis is stated to be significant. While the test results from an indirect effect, the hypothesis is significant. Hypothesis testing of direct influence is done by using t-test (t-test) on each path of influence between endogenous variables and exogenous variables.

Table 7 - Results of Direct and Indirect Influence Hypothesis Testing

\begin{tabular}{|c|c|c|c|c|}
\hline Direct Influence & Estimate & $\begin{array}{l}\text { T- } \\
\text { Statistic }\end{array}$ & $\begin{array}{l}\text { P- } \\
\text { Value }\end{array}$ & Description \\
\hline H1 : Organizational Culture (X) -> Employee Performance (Y) & 0.495 & 5.167 & 0.000 & Significant \\
\hline $\mathrm{H} 2$ : Organizational Culture $(\mathrm{X})->$ Work Ethics $(\mathrm{Z} 1)$ & 0.445 & 7.289 & 0.000 & Significant \\
\hline $\begin{array}{l}\text { H3 : Work Ethics }(\mathrm{Z} 1) \text {-> Employee Performance }(Y) \\
\text { Indirect Influence }\end{array}$ & 0.278 & 4.747 & 0.000 & Significant \\
\hline H4: Organizational Culture (X) -> Work Ethics (Z1) -> Employee Performance (Y) & 0.124 & 3.420 & 0.001 & Significant \\
\hline
\end{tabular}

Source: Analysis results processed, 2018.

Table 7 , the results of the analysis show that all hypotheses on direct and indirect effects show significant results so that it can be said that the Performance Variables are influenced by Work Culture, Employee Work Ethics.

Hypothesis 1: The Effect of Organizational Culture on Employee Performance.

Testing hypotheses with the PLS approach produces path coefficients of the influence of Organizational Culture on Employee Performance have a significant effect on the path coefficient of 0.495 and t-statistics of 5.167 with a p-value of 0.00 at $\alpha 5 \%$. Because the $p$ value is 0.00 smaller than 0.05 , there is enough empirical evidence to accept $\mathrm{H} 1$ : which states that there is a significant influence on Organizational Culture on Employee Performance. The coefficient positive sign indicates that the better the Organizational Culture the better the Employee Performance will be..

Hypothesis 2: The Influence of Organizational Culture on Work Ethics.

Hypothesis testing with the PLS approach produces a path coefficient of the influence of Organizational Culture on Work Ethics has a significant effect on the path coefficient of 0.445 and t-statistics of 7.289 with a p-value of 0.00 at $\alpha 5 \%$. Because the p-value is 0.00 less than 0.05 , there is enough empirical evidence to accept $\mathrm{H} 1$ : which states that there is a significant influence on Organizational Culture on Work Ethics. Coefficients with positive signs indicate that the better the Organizational Culture, the better the Work Ethics will be.

Hypothesis 3: The Effect of Work Ethics on Employee Performance.

Testing the hypothesis with the PLS approach produces a path coefficient of the effect of Work Ethics on Employee Performance has a significant effect on the path coefficient of 0.278 and t-statistics of 4.747 with a p-value of 0.00 at $\alpha 5 \%$. Because the p-value is 0.00 smaller than 0.05 , there is enough empirical evidence to accept $\mathrm{H} 1$ : which states that there is 
a significant influence on work ethics on employee performance. The coefficient positive sign indicates that the better the Work Ethic, the better the Employee Performance will be.

\section{Hypothesis 4: Influence of Organizational Culture on Employee Performance mediated by Work Ethics.}

Indirect influence between Organizational Culture on Performance through Work Ethics, obtained indirect coefficient of influence of 0.124 . Direct influences (Organizational Culture to Work Ethics, and Work Ethics to Performance) are both significant, based on pvalue $<0.05$, so it can be concluded that there is a significant indirect effect between Organizational Culture on Performance through Work Ethics. This means that the higher the Organizational Culture value, the higher the Performance value, if the value of Work Ethics is also high.

\section{DISCUSSION OF RESULTS}

Influence of Organizational Culture on Employee Performance. The results of this study indicate that organizational culture influences performance. This result means that good organization culture can improve the performance at PT. Bank Negara Indonesia Tbk. Kediri Branch. This finding supports the opinion of Suharto \& Nusantoro (2018), Raharjo et al., (2018), Calciolari et al., (2018), Aasi et al., (2018), Daulay and Pratiwi (2014) that organizational culture positively influences performance. Organizational culture will certainly bring various impacts on Human Resources (HR), so that employees of an organization must be able to respond to the organizational culture properly. Besides that the organizational culture that works well will certainly bring the organization to get its goals and the role of culture in the organization is very important, where culture can be a characteristic of an organization and differentiate it from other organizations Giani and Mukzam (2017).

In addition, the results of this study are the same as those conducted by Anggraeni (2008), Andino and Novadjaja (2015), Puspita Sari (2007), and Maramis (2013) which prove that organizational culture directly affects performance. As stated by Wardani, Mukzam, and Mayowan (2016) which states that organizations with a strong culture will influence the behavior and effectiveness of employee performance. The results of previous studies differ from this research, namely Susanti (2017) argues that organizational culture has a positive but not significant effect on employee performance. This is because the values and norms that have not been well received and understood by employees as a basis in the rules contained in the organization, as well as the presence of anxiety in the face of problems of external adaptation and internal integration. Muarif, Munazar, Bernhard Tewal, and Greis Sendow (2015) research also suggested that organizational culture had no significant effect on employee performance.

The empirical findings are based on the loading factor of the organizational culture variable for the aggressive indicator with the smallest loading. These results indicate that aggressiveness is reflected through being interested in learning new things outside of their work with the aim of enriching the knowledge they possess (X1.6.1) and creating a healthy competitive atmosphere between employees (X1.6.2) is still less applied to the BNI branch of Kediri. Independence shows how far people are aggressive and competitive rather than relaxed. These findings provide important recommendations for employees at BNI Kediri branch to be more aggressive in doing the job.

Research in the banking sector is interesting and needs to be studied about the behavior and effectiveness of employee performance considering that banks play an important role as financial institutions with the main task of collecting funds from the public, which is a successful banking record, of course, reliable human resources are needed. an indication for the bank, that the bank concerned has the trust of the community. The results of the empirical study found that organizational culture at PT. Bank Negara Indonesia Tbk. The Kediri Branch Office needs to be improved again so as to have an impact on improving performance. The research results proved that organizational culture has not been optimally implemented at PT. Bank Negara Indonesia Tbk. Kediri Branch Office. The findings show that the indicators that most reflect the organizational culture are the orientation of the results 
reflected through the awarding of the results achieved by employees and respecting the work of employees rather than the work process. Based on the results of research and theoretical support, the bank more optimize the organizational culture in order to create better performance in the future.

The influence of organizational culture on work ethics. Organizational culture influences performance. This result means that a good organizational culture will improve the work ethic. An organization needs a strong organizational culture, as stated by Sathe (1985) stating that the strength of corporate culture can be characterized by the homogeneity and stability of members of a company's organization when in a long and intense shared experience. In addition to a group of organizational members if successful in overcoming problems related to maintaining organizational sustainability in the long term, varied and high intensity experience, will strengthen the corporate culture and differentiate between one company and another. Whereas a weak organizational culture as stated by Susanto (2004) explains that a weak corporate culture is not able to provide encouragement to employees to have a desire to move forward with the company. Characteristics of a weak corporate culture are not having clear values or beliefs about efforts to succeed in the business, even though they may have many beliefs but are not agreed upon as important.

The results of this study are in line with the research conducted by Nurhakim (2007), Semedi (2009) that the relationship of corporate organizational culture to work ethics that has a strong relationship, namely a strong corporate culture will make a high professional work ethic. A high work ethic usually arises because of various interesting challenges, hopes, and possibilities. Such a situation can make people work diligently, conscientiously, dedicated, and with great responsibility (Widodo and Yuwantono, 2017).

The findings of this study indicate that organizational culture still needs to be improved to achieve a good work ethic at PT Bank Negara Indonesia Kediri Branch. The existence of a good organizational culture can help improve the work ethic. This is because the work ethic is an important factor in any organization, especially at PT Bank BNI. Based on the results of this study it is expected that banking organizations, especially at PT Bank BNI, can improve organizational culture.

Effect of Work Ethics on Performance. Work ethic has a positive effect on performance. This result means that a good work ethic will improve performance. The results of this study are in line with research conducted by Sapada et al., (2018), Osibanjo et al., (2018), Mohammad et al., (2018), Meriac \& Gorman. (2017), Goebel \& Weißenberger(2017), Luthfia et al, (2017), Timbuleng and Sumarauw (2015) that the work ethic affects performance. Employees who have a good work ethic will try to show an attitude, character and belief in carrying out a job by acting and working optimally (Octarina, 2013).

The results of other research studies that are different from this research are Febriantoro (2016) arguing that the work ethic does not significantly influence employee performance. Dodi, et al, (2013) explains that the work ethic is an attitude, views, habits, characteristics or attributes about how to work owned by a person, a class or a nation. Work ethic is the spirit of work seen in the way a person responds to a job, the motivation behind a job (Fadillah, 2010). The result stated that there is work ethic in PT BNI branch organization. This is evident that there is employee participation in terms of enthusiasm in completing work in order to get satisfactory results, complete even difficult work, obey the rules, carry out orders correctly, be honest, diligent in completing work and want to learn from mistakes to complete the work more satisfying.

The dominant factor influencing work ethic in this research is hard work and discipline, honesty and responsibility is important at PT. Bank Negara Indonesia Tbk. Kediri Branch. According to Salamun et al. (1995) an employee who has a high work ethic is indicated by: (1) hard work, where employees have the character of being drunk to be able to achieve the goals to be achieved, (2) work discipline, where employees have an attitude of respect, respect obedient and obedient to the regulations that apply, (3) honest, where employees in carrying out their work in accordance with the rules that have been determined, (4) responsibility, where the work done is something that must be done with diligence and sincerity, (5) diligently, the creation of personal habits of employees to maintain and improve 
what has been achieved, and (6) diligent means diligent, hard-hearted, and earnest (work, study and effort). Referring to the results of the research is expected that the Bank improve the work ethic of employees through hard work and discipline, honest and responsibility. With an optimal work ethic, there is an increase in performance.

The findings in this study indicate that the smallest diligent and diligent indicator (Z1.4) with the outer loading reflected through not easily bored and diligent in completing the work (Z1.4.1) and Want to learn from mistakes to complete a more satisfying job (Z1. 4.2). These findings illustrate the indicators of Diligent and Diligent (Z1.4) are still lacking in BNI Kediri branch. Thus these findings provide recommendations of the importance of diligent and diligent so as to contribute to employee performance.

The Influence of Culture on Performance through Work Ethics. The results of the study prove the influence of organizational culture on performance through work ethics. This shows that the work ethic is able to mediate the influence of organizational culture on performance. With the existence of an organizational culture, employees are encouraged to carry out new innovations, develop their capabilities. Gives more focus on the results achieved.

Organizational performance in this study is reflected in the form of factors of quantity, quality, timeliness, effectiveness and presence. The most influencing factor is the effectiveness of the maximum utilization of resources and time in the organization to increase profits and reduce losses, in addition the level of employee presence in the company can determine employee performance.

Based on the perceptions of employees, PT Bank Negara Indonesia (PERSERO) Tbk. Kediri Branch was more focused on all performance indicators, namely quality, quantity, on time, effectiveness and attendance; this was evidenced by the average of all indicators in the high category. In addition to indicators that affect performance, other factors that influence performance achievement are knowledge, skills, and motivation factors. Thus the performance needs to be upgraded to achieve the mission vision of PT BNI Kediri branch.

\section{CONCLUSION AND RECOMMENDATIONS}

Results of the study it can be concluded that organizational culture has a direct effect on employee performance, organizational culture influences the work ethic, work ethic directly affects the performance of Kediri branch employees of Bank Negara Indonesia and the culture of organization influences performance through work ethic. This the study recommends that the Kediri branch of Bank Negara Indonesia leaders pay attention to the importance of an organizational culture that has the characteristics of risk-taking innovation, detail attention, results orientation, human orientation, team orientation, aggressiveness and stability can improve employee performance at PT Bank Negara Indonesia (PERSERO) Tbk. Kediri Branch. This is based on the findings of a strong organizational culture in measuring performance. Thus the leadership can direct and remind employees of the importance of organizational culture.

\section{REFERENCES}

1. Aasi, P., Rusu, L., Leidner, D., Perjons, E., \& Corrales Estrada, M. 2018. How Does the Organizational Culture of Collaborative Networks Influence IT Governance Performance in a Large Organization?.

2. Alainein.A., A. 2016. The Effect Of Job Involvement On Job Performance At UNRWA Gaza Field Office. Theses Of Islamic University of Gasa.

3. Andino, H. A., \& Novadjaja, L. H. 2015. Pengaruh Budaya Organisasi Terhadap Kinerja Karyawan PT. Bank Pembangunan Daerah Jawa Timur tbk.Bank Jatim Kantor Pusat Surabaya. Jurnal IImiah Mahasiswa FEB, 41.

4. Anggraeni, L. 2008 Pengaruh budaya organisasi terhadap kinerja karyawan Kantor Besar PT Bank Indonesia Persero TBK. Jakarta, Tugas Akhir. Universitas Telkom University. 
5. Calciolari, S., Prenestini, A., \& Lega, F. 2018. An organizational culture for all seasons? How cultural type dominance and strength influence different performance goals. Public Management Review, 20(9), 1400-1422.

6. Daulay, I. N., \& Pratiwi, A. 2014. Pengaruh Lingkungan Kerja dan Budaya Organisasi terhadap Kinerja Karyawan PT. Bank Riau Kepri Capem Duri. Jurnal Online Mahasiswa Fakultas Ekonomi Universitas Riau, 1(2).1-15.

7. Dodi, dkk. 2013. Pengaruh Iklim Organisasi, Etos Kerja dan Disiplin terhadap Kinerja Karyawan serta Dampaknya pada Kinerja PT. Arun NGL Lhokseumawe Aceh. Jurnal Manajemen. 2(1), pp $98-107$.

8. Fadillah, Candra. 2010. Tingkat Pendapatan dan Pengaruhnya terhadap Etos Kerja Guru dalam Mengajar. Tesis. Jakarta: UIN Syarif Hidayatullah.

9. Febriantoro, N. M. 2016. Pengaruh etos kerja islam dan komitmen organisasi terhadap kinerja karyawan studi kasus pada Bank Syariah Mandiri Kc Ciputat Bachelor's thesis, UIN Syarif Hidayatullah Jakarta: Fakultas Ekonomi dan Bisnis, 2016.

10. Ghozali, Imam. 2011. Aplikasi Analisis Multivariate Dengan Program SPSS”. Semarang: Badan Penerbit Universitas Diponegoro.

11. Giani Muhammad, E. Z., \& Mukzam, M. D. 2017. Pengaruh Budaya Organisasi Terhadap Kinerja Karyawan Studi pada Karyawan Bank BRI Kantor Cabang Tuban. Jurnal Administrasi Bisnis, 53(1), 89-95.

12. Goebel, S., \& Weißenberger, B. E. (2017). The relationship between informal controls, ethical work climates, and organizational performance. Journal of business ethics, 141(3), 505-528.

13. Greenberg, J. And Robert A. Baron. 2003. Behavior in Organization International Edition, New Jersey: Prentice Hall.

14. Luthfia, S. M., Djaelani, A. Q., \& Slamet, A. R. 2017. Pengaruh etos kerja, disiplin kerja dan komitmen organisasi terhadap kinerja pegawai kantor kementrian agama kota batu. Jurnal IImiah Riset Manajemen, 6(4), 90-100.

15. Maramis, E. 2013. Kepemimpinan, Budaya Organisasi, Dan Motivasi Pengaruhnya Terhadap Kinerja Karyawan Pada Pt. Bank Tabungan Negara Persero Cabang Manado. Jurnal EMBA: Jurnal Riset Ekonomi, Manajemen, Bisnis dan Akuntansi, 14.

16. Meriac, J. P., \& Gorman, C. A. 2017. Work ethic and work outcomes in an expanded criterion domain. Journal of Business and Psychology, 32(3), 273-282.

17. Mohammad, J., Quoquab, F., Idris, F., Al-Jabari, M., Hussin, N., \& Wishah, R. 2018. The relationship between Islamic work ethic and workplace outcome: A partial least squares approach. Personnel Review.

18. Muarif, M. R., Tewal, B., \& Sendow, G. M. 2015. Gaya Kepemimpinan Transformasional, Budaya Organisasi, Keterlibatan Kerja Pengaruhnya terhadap Kinerja Karyawan Bank Syariah Mandiri Cabang Manado. Jurnal EMBA: Jurnal Riset Ekonomi, Manajemen, Bisnis dan Akuntansi, 3(3).

19. Nurhakim, L. 2007. Pengaruh Budaya Organisasi terhadap Etos Kerja serta Dampaknya terhadap Kinerja Karyawan Lulusan Akademi Komunitas Toyota Indonesia. Institut Pertanian Bogor..

20. Octarina, A. 2013. Pengaruh Etos Kerja Dan Disiplin Kerja Terhadap Kinerja Pegawai Pada Dinas Kebudayaan Pariwisata Pemuda Dan Olahraga Kabupaten Sarolangun. Manajemen S-1, 1(1), 1-15

21. Osibanjo, A. O., Akinbode, J., Falola, H. O., \& Oludayo, O. O. 2018. Work ethics and employees' job performance. Journal of Leadership, Accountability and Ethics, 12(1), 107-117.

22. Paschal, A. O., \& Nizam, I. 2016. Effects of Organisational Culture on Employees Performance: Case of Singapore Telecommunication. 4(1), 19-26.

23. Puspita Sari, I. 2007. Pengaruh Budaya Organisasi Terhadap Kinerja Karyawan PT. BANK BII Studi terhadap Karyawan PT. Bank BII Cabang Malang di Jl. BasukiRahmat No. 9193 Malang Doctoral dissertation, University of Muhammadiyah Malang. 
24. Raharjo, K., \& Achmad Rinaldo Fernandes, A. 2018. The influence of organizational culture and job design on job commitment and human resource performance. Journal of Organizational Change Management.

25. Robbins, Stephen P. 2001. Perilaku Organisasi: Konsep, Kontroversi, Aplikasi, Jilid 1, Edisi 8, Prenhallindo, Jakarta.

26. Salamun, Sumardi, Sadilah, Emiliana, Sumintarsih, Sudijono, dan Suhartinah. 1995. Persepsi Tentang Etos Kerja: Kaitannya Dengan Nilai Budaya Masyarakat Daerah Istimewa Yogyakarta. Yogyakarta: Departemen Pendidikan Dan Kebudayaan RI.

27. Sapada, A. F. A., Modding, H. B., Gani, A., \& Nujum, S. 2018. The effect of organizational culture and work ethics on job satisfaction and employees performance.

28. Sathe, V., 1985. Corporate and Related Corporate Realities, Homewood, Illinois.

29. Semedi, S. N. 2009. Pengaruh Budaya Perusahaan Terhadap Etos Kerja Profesional Serta Kaitannya Dengan Peningkatan Kinerja Perusahaan Jasa Konsultan. Penerbit PT. PPA Consultants, Jakarta.

30. Suharto, S., \& Nusantoro, J. 2018. The Relationship Among Managerial Capability, Organizational Citizenship Behavior, And Employee Performance: Mediation Effects Of Organizational Culture. Journal of Community Research and Service, 2(1), 168-175.

31. Susanti, N. I. 2017. Pengaruh Keterampilan Interpersonal, Etos Kerja Islam, Dan Budaya Organisasi Terhadap Kinerja Karyawan. Jurnal Ekonomi Islam, 9(1), 100-120.

32. Susanto, A.B., 2004. Menjadi Supercompany Melalui Budaya Organisasi yang Tangguh.

33. Timbuleng, S., \& Sumarauw, J. S. 2015. Etos Kerja, Disiplin Kerja, Dan Komitmen Organisasi Pengaruhnya Terhadap Kinerja Karyawan Pada Pt Hasjrat Abadi Cabang Manado. Jurnal EMBA: Jurnal Riset Ekonomi, Manajemen, Bisnis dan Akuntansi, 3(2).1051-1060

34. Wardani, R. K., Mukzam, M. D., \& Mayowan, Y. 2016. Pengaruh Budaya Organisasi Terhadap Kinerja Karyawan Studi Pada Karyawan PT Karya Indah Buana Surabaya. Jurnal Administrasi Bisnis, 31(1), 58-65.

35. Widodo, W., \& Yuwantono, N. 2017. Pengaruh budaya organisasi dan etos kerja terhadap kinerja karyawan PT. Gemilang Jaya. Jurnal Manajemen Bisnis Krisnadwipayana, 5(2).1-14. 